\title{
Public Perception of COVID-19 Vaccines through Analysis of Twitter Content and Users
}

${ }^{1}$ Department of Internal Medicine, University of Texas Southwestern Medical Center, 5323 Harry Hines Boulevard, Dallas, TX 75390

${ }^{2}$ Clinical Informatics Center, University of Texas Southwestern Medical Center, 5323 Harry Hines Boulevard, Dallas, TX 75390

${ }^{3}$ Department of Emergency Medicine, University of Texas Southwestern Medical Center, 5323 Harry Hines Boulevard, Dallas, TX 75390

${ }^{4}$ Lebanon Trail High School, 5151 Ohio Dr, Frisco, TX 75035

${ }^{5}$ Departments of Pediatrics, Bioinformatics, Population \& Data Sciences, University of Texas Southwestern Medical Center, 5323 Harry Hines Boulevard, Dallas, TX 75390

\section{Corresponding Author:}

Sameh N. Saleh, MD

5323 Harry Hines Blvd, Dallas, TX 75219

M: $571-338-3680$

F: $214-648-9478$

E: sameh.n.saleh@gmail.com

\section{Keywords:}

COVID-19, Vaccine, Twitter, Social Media, Public Opinion, COVID-19 Vaccines, SARS-CoV2, Vaccination, Vaccination Refusal, Vaccine Hesitancy, Natural Language Processing, Sentiment Analysis, Topic Modeling, Demographic Inference 
medRxiv preprint doi: https://doi.org/10.1101/2021.04.19.21255701; this version posted April 22, 2021. The copyright holder for this preprint (which was not certified by peer review) is the author/funder, who has granted medRxiv a license to display the preprint in perpetuity.

It is made available under a CC-BY-NC-ND 4.0 International license .

\section{Abstract}

36 Twitter is a robust medium to understand wide-scale, organic public perception about the

37 COVID-19 vaccine. In this cross-sectional observational study, we evaluated 2.4 million English

38 tweets from nearly 1 million user accounts matching keywords (('covid*' OR 'coronavirus')

39 AND 'vaccine') during vaccine development from Feb $1^{\text {st }}$ through Dec $11^{\text {th }}, 2020$. We applied

40 topic modeling, sentiment and emotion analysis, and demographic inference of users on the

41 COVID-19 vaccine related tweets to provide insight into the evolution of public attitudes.

42 Individuals generated $87.9 \%(\mathrm{n}=834,224)$ of tweets. Of individuals, men $(\mathrm{n}=560,824)$

43 outnumbered women $(n=273,400)$ by $2: 1$ and $39.5 \%(n=329,776)$ of individuals were $\geq 40$ years

44 old. Daily mean sentiment fluctuated congruent with news events, but overall trended positively.

45 Trust, anticipation, and fear were the three most predominant emotions; while fear was the most

46 predominant emotion early in the study period, trust outpaced fear from April 2020 onward. Fear

47 was more prevalent in tweets by individuals (26.3\% vs. organizations 19.4\%; p<0.001),

48 specifically among women (28.4\% vs. males $25.4 \%$; $\mathrm{p}<0.001)$. Multiple topics had a monthly

49 trend towards more positive sentiment. Tweets comparing COVID-19 to the influenza vaccine

50 had strongly negative early sentiment but improved over time. Our findings are concerning for

51 COVID-19 vaccine hesitancy, but also identify targets for educational interventions. 
medRxiv preprint doi: https://doi.org/10.1101/2021.04.19.21255701; this version posted April 22, 2021. The copyright holder for this preprint (which was not certified by peer review) is the author/funder, who has granted medRxiv a license to display the preprint in perpetuity.

\section{Introduction}

54 With the global continuation of the COVID-19 pandemic, the large-scale administration of a

55 SARS-CoV-2 vaccine (referred from here on as the COVID-19 vaccine) is crucial to achieve

56 herd immunity and curtail further spread of the virus ${ }^{1}$. As governments work to approve and

57 distribute safe and effective vaccines, ${ }^{2}$ important questions regarding vaccination willingness

58 persist: What are the attitudes and perceptions of the public ${ }^{3}$ to these vaccines and how can they

59 affect vaccine uptake ${ }^{4}$ ? These questions are important to develop an education and outreach

60 approach to achieve the desired vaccine penetration to achieve herd immunity ${ }^{5}$. In 2019 , prior to

61 the COVID-19 pandemic, the World Health Organization (WHO) had identified vaccine

62 hesitancy as one of the top 10 greatest global health threats ${ }^{6}$. While surveys on attitudes and

63 perception of a COVID-19 vaccine show significant vaccine hesitancy among the general

64 population $^{7-9}$ and health care providers ${ }^{10,11}$, studies remain small in size, tend to focus on local

65 participants, are prone to sampling error from non-probability sampling and reporting bias, and

66 perhaps most poignantly, cannot capture real-time changes in vaccine willingness. Crowdfunding

67 platforms may provide an indication of emerging community needs related to COVID-19 but fail

68 to provide a continuous assessment of community sentiment ${ }^{12}$.

70 Twitter, the microblogging platform, with over 187 million daily monetizable active users, ${ }^{13}$

71 serves as a robust medium to better understand wide-scale, organic public perception about the

72 COVID-19 vaccine. With nearly 400 million mentions, \#COVID19 was the most used hashtag

73 on Twitter in $2020^{14}$. Social media has become increasingly recognized for its rapid information

74 dissemination (whether accurate or not) and dispersion of sentiment that quickly crosses

75 geographic and social boundaries ${ }^{15}$. Analysis of social media text can inform real-time changes 
medRxiv preprint doi: https://doi.org/10.1101/2021.04.19.21255701; this version posted April 22, 2021. The copyright holder for this preprint (which was not certified by peer review) is the author/funder, who has granted medRxiv a license to display the preprint in perpetuity. It is made available under a CC-BY-NC-ND 4.0 International license .

76 and evolution in population-level attitudes ${ }^{16}$. As evident with the rise of the "infodemic" during

77 the COVID-19 pandemic, Twitter has become a particularly useful data source in public health

78 and healthcare-related research ${ }^{17}$ and has been repeatedly used to study public sentiment and

79 understand trends throughout the COVID-19 pandemic $^{18-21}$. Earlier in the COVID-19 pandemic,

80 we were able to demonstrate initial public sentiment regarding the virus, its origin and spread,

81 and measures to limit its spread ${ }^{22}$ as well as early support for social distancing ${ }^{23}$ on Twitter.

83 Social media, and specifically Twitter, has been shown to be a major factor in vaccine uptake

84 and should be monitored and potentially used for interventions to address vaccine hesitancy ${ }^{24}$.

85 Examining sentiments towards the influenza A H1N1 vaccine in 2009 showed that projected

86 vaccination rates based on Twitter sentiment were similar to vaccination rates estimated by

87 traditional phone surveys used by the Centers for Disease Control and Prevention (CDC) ${ }^{25}$. A

88 previous study noted information exposure on Twitter may account for differences in human

89 papillomavirus (HPV) vaccine uptake that are not accounted for by socioeconomic factors like

90 education, insurance, or poverty ${ }^{26}$. Another study noted that there is a significant relationship

91 between social media use by the public and organized action and public doubts of vaccine 92 safety $^{27}$.

94 We aimed to apply content and sentiment analysis on COVID-19 vaccine related tweets as well

95 as analysis of the responsible, originating user accounts to provide insight into the evolution of

96 public attitudes about the COVID-19 vaccines over time. We hypothesized that content analysis

97 from the start of the pandemic will identify important themes of discussion (especially those with

98 negative sentiment or evidence of misinformation) throughout the vaccine development process 
medRxiv preprint doi: https://doi.org/10.1101/2021.04.19.21255701; this version posted April 22, 2021. The copyright holder for this preprint (which was not certified by peer review) is the author/funder, who has granted medRxiv a license to display the preprint in perpetuity. It is made available under a CC-BY-NC-ND 4.0 International license .

99 that would inform health care officials, public health agencies, and policy makers and could be

100 used to aid in the outreach and educational interventions for the COVID-19 vaccine to the 101 general public.

\section{Methods}

\section{Data Source}

104 We performed a cross-sectional observational study of English-language tweets obtained by 105 matching the keywords (('covid*' OR 'coronavirus') AND 'vaccine') from February 1, 2020 to

106 December 11th, 2020. December 11th was chosen as an end date to mark the United States Food 107 and Drug Administration's first emergency use authorization of a COVID-19 vaccine ${ }^{28}$. We used 108 the snscrape library ${ }^{29}$ to obtain ("scrape") tweets identified through Twitter's advanced search 109 tool, which returns a relevant sample of tweets. We manually reviewed a random subsample of 1101,000 tweets and verified the tweets' relevance to the topic of COVID-19 vaccination. We

111 extracted 21 and 20 variables related to the tweets and to the posting user accounts, respectively 112 (Supplemental Table S1 and S2).

\section{Data Processing}

114 We measured total daily tweets and completed descriptive statistics for collected variables. We 115 applied natural language processing techniques to process, analyze, and visualize the text from 116 tweets. To preprocess the tweet text for analysis (“cleaning”), we removed hyperlinks, user tags, 117 and words of little analytical value. We also returned words to their root form and segmented 118 text into one- and two-word terms. Further details are discussed in Supplemental Appendix A. 119 We visualized the top 300 processed terms as a word cloud with larger font size representing 120 greater term frequency. All analyses were conducted using Python, version 3.8.2 (Python 
medRxiv preprint doi: https://doi.org/10.1101/2021.04.19.21255701; this version posted April 22, 2021. The copyright holder for this preprint (which was not certified by peer review) is the author/funder, who has granted medRxiv a license to display the preprint in perpetuity. It is made available under a CC-BY-NC-ND 4.0 International license .

121 Software foundation). Institutional review board approval was not required because this study 122 used only publicly available data.

\section{Sentiment Analysis}

124 Sentiment analysis describes the affect of a piece of text - the intrinsic attractiveness or 125 aversiveness of a subject such as events, objects, or situations ${ }^{30}$. We used the Valence Aware 126 Dictionary and sEntiment Reasoner (VADER) ${ }^{31}$ to analyze the sentiment polarity of a tweet. 127 VADER, a lexicon and rule-based tool, was particularly designed for sentiment analysis for 128 social media text. In addition to regular words, VADER leverages punctuation, emoticons, 129 emojis, sentiment-laden slang words and acronyms, as well as syntax and capitalization schemas to inform labeling of a positive, neutral, and negative score for each document. These three

131 scores were combined to form a normalized, weighted composite score. Overall positive $(\geq 0.05)$, 132 neutral (-0.05 to 0.05$)$, and negative $(\leq-0.05)$ sentiments are defined at standardized composite

133 score thresholds. When sentiment has been aggregated, we refer to an average sentiment of $134 \geq 0.05$ as positive and $\leq-0.05$ as negative. Trends in sentiment over time were determined using 135 the Mann-Kendall trend test. We used the TextBlob library ${ }^{32}$ to label each tweet from a range of 1360 (objective) to 1 (subjective) where objective tweets relay factual information and subjective 137 tweets typically communicate an opinion or belief. Finally, we used the NRCLex library to label 138 words within each tweet with corresponding emotional affects (i.e., Plutchik's wheel of emotions 139 which include anger, anticipation, fear, disgust, joy, sadness, surprise, and trust) based on the 140 National Research Council Canada (NRC) affect lexicon ${ }^{33}$. Based on these labels, we identified 141 tweets with their primary emotion and visualized how the proportion of eligible tweets (i.e., 142 those with an identified primary emotion) with a particular primary emotion changed over time. 
medRxiv preprint doi: https://doi.org/10.1101/2021.04.19.21255701; this version posted April 22, 2021. The copyright holder for this preprint (which was not certified by peer review) is the author/funder, who has granted medRxiv a license to display the preprint in perpetuity.

\section{Topic Modeling}

144 After cleaning the tweets to distill analyzable text as described in the methods, we applied a 145 machine learning algorithm called Correlation Explanation (CorEx $)^{34}$ to identify clusters of 146 topics for all tweets. CorEx identifies the most informative topics based on a set of latent factors

147 that best explain the correlations in the data in turn maximizing the total correlation or the 148 multivariate mutual information ${ }^{35}$. Each document (in our case, each tweet) may include multiple 149 topics. We iterated through a range from 2 to 20 topics and trained a separate model for each 150 number of topics with the goal of identifying the model with the maximum total correlation,

151 ultimately choosing 15 topics for the topic model. We presented the top 20 words for each topic 152 cluster to author CUL without prior access to individual tweets from the dataset to manually 153 label a theme for each topic. The manually labeled topic labels were reviewed by two other 154 authors SNS and RJM with unanimous agreement. We visualized the monthly distribution of 155 topics over time and utilized a heat map to visualize how the mean sentiment of each topic has 156 changed per month.

\section{User Exploration and Demographic Inference}

158 Given that each tweet has one authoring account, we identified all unique user accounts in our

159 dataset and provided descriptive statistics with metadata available for the users, including the

160 launch date of the account, followers (accounts following them), follows (accounts they follow),

161 lifetime posts, likes, and media shared, as well as profile pictures, description information, and 162 verified status (badge to indicate an account of public interest that has been verified to be 163 authentic). To better understand demographic differences, we applied a previously validated 164 deep learning system through the m3inference library ${ }^{36}$ to infer the account user as an individual 165 or an organization and if labeled as an individual, their gender (female or male) and age group 
medRxiv preprint doi: https://doi.org/10.1101/2021.04.19.21255701; this version posted April 22, 2021. The copyright holder for this preprint (which was not certified by peer review) is the author/funder, who has granted medRxiv a license to display the preprint in perpetuity. It is made available under a CC-BY-NC-ND 4.0 International license .

166 ( $\leq 18$ years old, 19-29 years old, 30-39 years old, and $\geq 40$ years old) based on multimodal input

167 that includes username, display name, description, and profile picture image. Each label using

168 the algorithm has an accompanying probability. The automatic demographic detection was

169 particularly designed for Twitter profiles for health-related cohort studies ${ }^{37}$. We provided

170 summary statistics for the demographics identified and stratified sentiment and subjectivity

171 analyses by the different demographic groups to evaluate for differences. We used Mann-

172 Whitney $\mathrm{U}$ and $\chi^{2}$ where appropriate to determine significance. Alpha level of significance was

173 set a priori at 0.05 and all hypothesis testing was two-sided. We did not adjust for multiple

174 comparisons as this was an exploratory study and should be interpreted as hypothesis-generating.

\section{Results}

176 A total of 2,356,285 tweets were extracted for the study period, of which 2,287,344 tweets were

177 English-only and included for evaluation. The tweets were generated by 948,666 accounts which

178 had been active for an average of 6.9 years (interquartile range [IQR], 2.6 - 10.0) with a median

179 of 267 (IQR, 55 - 1,100) followers and 3,600 (519 - 15,572) lifetime likes. Only 2.9\%

$180(n=27,443)$ of accounts were verified (Table 1). Of the tweets analyzed, $54 \%(n=1,235,575)$ had

181 a link, 40.1\% ( $n=916,585)$ mentioned other twitter accounts, 18.1\% $(n=414,173)$ used hashtags,

182 and $11.9 \%(n=273,278)$ contained media like an image or video. In terms of engagement, $41.3 \%$

$183(n=943,639), 24.0 \%(n=548,863)$, and 20.7\% $(n=473,204)$ of tweets received likes, replies, and

184 retweets, respectively (Table 1$)$. Individuals (vs. organizations) generated $87.9 \%(n=834,224)$ of

185 tweets. Of individuals, men $(n=560,824)$ outnumbered women $(n=273,400)$ by $2: 1$ and $39.5 \%$ (n $186=329,776)$ of individuals were $\geq 40$ years old $($ Table 1$)$. 
medRxiv preprint doi: https://doi.org/10.1101/2021.04.19.21255701; this version posted April 22, 2021. The copyright holder for this preprint (which was not certified by peer review) is the author/funder, who has granted medRxiv a license to display the preprint in perpetuity. It is made available under a CC-BY-NC-ND 4.0 International license . 0.030; IQR, 0.012 to 0.044) (Figure 2b-d).

Daily tweets abruptly spiked to 51,176 tweets on November $9^{\text {th }}$, the day Pfizer and BioNTech announced their vaccine's effectiveness ${ }^{38}$ (up from 4,052 tweets on November $8^{\text {th }}$ ) and peaked on December $8^{\text {th }}$ with 55,779 tweets. Tweets from November $1^{\text {st }}$ to the end of the study period on December 11th accounted for 39.8\% $(\mathrm{n}=910,593)$ of all tweets (Figure $\mathrm{S} 1)$. The corpus of tweets contained over 62.5 million words and 416 million characters. The ten most commonly tweeted terms and their frequencies were as follows: "people" $(228,482)$, "trial" $(206,310)$, “take” (181,598), “flu” (159,043), "trump" (149,042), "first” (147,103), “make” $(142,242)$, "test” $(131,719)$, "need" $(126,846)$, and "one" $(122,966)$. Figure 1 displays a word cloud of the top 300 words with larger font size concordant with frequency.

Daily mean sentiment of tweets fluctuated congruent with news events, but overall trended positively throughout the study period (Mann-Kendall statistic=10,122; tau=0.218; $\mathrm{p}<0.001$ ) (Figure 2a). Several days in early to mid-March and on October 13th saw particularly negative sentiments, coinciding with news of the declaration of a pandemic by the WHO and Johnson \& Johnson's halting of their vaccine trial on October $12 \mathrm{th}^{39}$, respectively. Highest daily mean positive sentiment revolved around Moderna's July 14th announcement of a safe vaccine with "robust immune response" in an early trial ${ }^{40}$ and Pfizer's November 9th announcement of over $90 \%$ effectiveness of its vaccine ${ }^{38}$. Twitter accounts representing organizations had more positive sentiments than tweets from individuals (median weekly difference, 0.118; IQR, 0.091 to 0.144), but there was no significant difference in polarity for age (median weekly difference, 0.006; IQR, -0.011 to 0.019) and only minimal positive difference for males (median weekly difference, 
medRxiv preprint doi: https://doi.org/10.1101/2021.04.19.21255701; this version posted April 22, 2021. The copyright holder for this preprint (which was not certified by peer review) is the author/funder, who has granted medRxiv a license to display the preprint in perpetuity. It is made available under a CC-BY-NC-ND 4.0 International license .

211 The sentiment trends were reflected by the primary emotions identified in the COVID-19

212 vaccine tweets by month (Figure 3a). Fear started as the most prevalent primary emotion in

213 nearly $40 \%$ of eligible tweets early on but decreased to under $20 \%$ by the end of the study

214 period. Conversely, trust increased from below $20 \%$ to around $40 \%$ and outpaced fear in April

215 2020, maintaining as the most prevalent primary emotion thereafter. Anticipation was the second

216 most prevalent primary emotion for most of the study period, steadily ranging from $25 \%$ to $30 \%$.

217 All other emotions were consistently expressed as the predominant emotion in less than $10 \%$ of

218 eligible tweets. Individuals had an increased predominance of fear $(26.3 \%$ vs. $19.4 \% ; \mathrm{p}<0.001)$

219 and decreased predominance of anticipation $(25.9 \%$ vs. $33.6 \%$; $\mathrm{p}<0.001)$ and trust $(32.5 \%$ vs.

$22035.2 \% ; \mathrm{p}<0.001)$. For individual accounts, women had more fear $(28.4 \%$ vs. males $25.4 \%$;

$221 \mathrm{p}<0.001)$ with less anticipation $(23.8 \%$ vs. $26.8 \%$; $<<0.001)$ than men, but no significant

222 difference in trust (32.3\% vs. $32.5 \%, \mathrm{p}=0.11)$. Those less than 40 years old had more fear $(26.6 \%$

223 vs. 26.0\%; p<0.001) and less trust (32.0\% vs. 33.0\%; p<0.001) (Figure 3b-d). Tweets throughout

224 the year tended to be more objective (where 0 is fully objective and 1 as fully subjective) with

225 limited daily variation (overall mean 0.359; std 0.028) (Figure S2).

227 Table 2 shows each topic label with their key words and sample tweets. Figure S3 shows the 15

228 topics obtained from topic modeling with the proportion of tweets per month that contained each

229 topic. The dominant topic (topic 15) focused on mask use and public reactions. Discussions

230 about misinformation and conspiracy theories comprised the next most common topic, peaking

231 in May and staying relatively consistent from July through December. Tweets related to the

232 Indian and Russian governments' decision on producing and using the Sputnik V vaccine (topic

233 2) spiked in August. Discussion of Emergency Use Authorizations (EUA) and vaccine approvals 
medRxiv preprint doi: https://doi.org/10.1101/2021.04.19.21255701; this version posted April 22, 2021. The copyright holder for this preprint (which was not certified by peer review) is the author/funder, who has granted medRxiv a license to display the preprint in perpetuity. It is made available under a CC-BY-NC-ND 4.0 International license .

234 (topic 12) did not spike until November 2020 with the approval of the Pfizer and Moderna

235 vaccines. Several topics had strong mean positive sentiments throughout the study period,

236 including discussions of biotechnology companies and the stock market (topic 3), vaccination

237 firsts (topic 4), vaccine development (topic 6), and EUAs (topic 12). Other topics showed a 238 progressive trend from positive to negative throughout the study period including discussion of

239 US politics and the election (topic 1), the FDA and CDC (topic 14), and mask use and public 240 reactions (topic 15). Tweets comparing COVID-19 to influenza (topic 5) and its vaccine had

241 strongly negative early sentiment but improved over time (Figure 4). Compared to the rest of 242 individual users $(\mathrm{n}=810,318)$, those exhibiting negative sentiment posting about topic 5

$243(\mathrm{n}=51,686)$ were proportionally more likely to be $\geq 40$ years old $(45.1 \%$ vs. $39.6 \% ; \mathrm{p}<0.001)$ and

244 female $(34.0 \%$ vs. $32.7 \%$; p <0.001). The only other topic with persistently negative sentiment 245 was discussion of misinformation and conspiracy theories (topic 13). Those exhibiting negative 246 sentiment posting about topic $13(n=166,819)$ were more likely than other user accounts $247(\mathrm{n}=741,388)$ to be individuals $(90.9 \%$ vs. $87.3 \% ; \mathrm{p}<0.001)$ and of those individual accounts, 248 more likely to be female $(34.4 \%$ vs. $32.4 \% ; \mathrm{p}<0.001)$.

\section{Discussion}

250 Twitter is a rich medium that can serve as both thermometer and thermostat for the COVID-19

251 vaccine, which is a crucial public health strategy to combat the pandemic. It can provide insight 252 into public perception of a COVID-19 vaccine, but can also be used to understand and combat

253 knowledge deficits and vaccine hesitancy through information and education ${ }^{41,42}$. A majority

$254(59 \%)$ of US Twitter users regularly obtain news on Twitter, proportionally more than any other

255 social media platform ${ }^{43}$. We analyzed nearly 2.4 million COVID-19 vaccine related tweets in

2562020 , creating a dataset that exceeded the scope of related studies ${ }^{44,45}$. Generally, we believe that 
medRxiv preprint doi: https://doi.org/10.1101/2021.04.19.21255701; this version posted April 22, 2021. The copyright holder for this preprint (which was not certified by peer review) is the author/funder, who has granted medRxiv a license to display the preprint in perpetuity. It is made available under a CC-BY-NC-ND 4.0 International license .

257 Twitter users favored the vaccine during its development phase. Tweets with positive sentiment 258 were more prominent than tweets with negative sentiment and trust emerged as the predominant 259 emotion. However, there were periods of time (usually linked to events in the public news cycle), 260 demographic subgroups, and topic clusters that had more prominent negative sentiment and 261 emotion.

Organizational accounts were significantly more positive, exhibiting more anticipation and trust

264 and less fear. For individuals, the gender and age distribution in our dataset parallels the reported

265 proportional share of Twitter's global advertising audience ${ }^{46}$. Women expressed more fear and

266 less anticipation, but by the end of the study period, that gap had narrowed. Those less than 40

267 years old tended to express less trust and more fear, but the margin was small.

269 The topic most strongly associated with negative, albeit improving, sentiment was the discussion

270 of the influenza vaccine in combination with the COVID-19 vaccine. These tweets often

271 compared deaths and illness from both diseases or expressed general vaccine mistrust to both

272 vaccines. Examples include: “@[user] Only time I've ever had the flu is the 2 times I got flu

273 shots. It was not a minor case either it was the full blown flu. I refuse to get another flu shot and

274 I also will refuse the covid vaccine" and "Flu Virus equals Flu Vaccine. Coronavirus Equals

275 Covid-19 Vaccine...Now if the Flu shot gives you the flu, the Covid-19 Shot will give you

276 Coronavirus....am I in the general area of Right??”. Notably, these users exhibiting negative

277 sentiment about this topic were more likely to be $\geq 40$ years old and female. This focused topic-

278 demographic cluster, for example, exposes a direct opportunity for intervention to correct 
medRxiv preprint doi: https://doi.org/10.1101/2021.04.19.21255701; this version posted April 22, 2021. The copyright holder for this preprint (which was not certified by peer review) is the author/funder, who has granted medRxiv a license to display the preprint in perpetuity.

It is made available under a CC-BY-NC-ND 4.0 International license .

279 misinformation and mitigate vaccine hesitancy. Conversely, the emergency use authorizations of

280 the vaccine and reports of the first vaccine recipients, which arose later in the study period, were

281 celebrated with positive sentiment and mirror the overall increasing trend in positive sentiment

282 and trust.

284 While the percent population immunity needed to achieve herd immunity (either through innate

285 or acquired immunity) for COVID-19 is not yet known, estimates have increased from 60-70\%

286 to possibly closer to $75-85 \%^{47,48}$. Achieving herd immunity through infection would come at an

287 untenable $\operatorname{cost}^{49}$, making the immunization effort critical to protect lives. Therefore, it was

288 concerning to us that fear was a common and persistent predominant emotion in COVID-19

289 vaccine tweets. While the proportion of 'trust' tweets outpaced 'fear' tweets relatively early in

290 the study period, approximately $20 \%$ of eligible tweets still expressed fear in association with the

291 vaccine. If this fear translates into refusal to become immunized, we are not only likely to see a

292 prolonged pandemic, but also further increases in COVID-19 related deaths as concerning virus

293 variants take hold. As more people receive the vaccine in the future, we anticipate that

294 sentiments will become more positive over time with increased trust and vaccine uptake, but this

295 will need to be consistently studied especially in the context of newly approved vaccines and

296 news events.

\section{Limitations}

298 Our study was limited by several factors. First, we recognize that our dataset is not all inclusive

299 of tweets discussing the COVID-19 vaccine. Our tweet search criterion was narrow to ensure

300 accuracy of captured tweets for this initial work and did not include terms such as "shot(s)",

301 "immunization" and "inoculation." Moreover, despite the volume of tweets analyzed, we are 
medRxiv preprint doi: https://doi.org/10.1101/2021.04.19.21255701; this version posted April 22, 2021. The copyright holder for this preprint (which was not certified by peer review) is the author/funder, who has granted medRxiv a license to display the preprint in perpetuity.

It is made available under a CC-BY-NC-ND 4.0 International license .

302 limited to only a relevant sample of all tweets per Twitter's advanced search tool. Second, we

303 used existing tools to analyze sentiments and emotion of tweets that are not specific to health

304 care topics, which could have skewed our analysis. Third, tweets related to COVID-19

305 vaccination could have been flagged or removed by Twitter for containing misinformation, but

306 we were not privy to that context to determine how that could have affected our sample. Finally,

307 since we targeted only tweets in English and are unable to determine geographic location for

308 users, we are limited in making conclusions about specific countries or countries where English

309 is the not the predominant language.

\section{Conclusions}

311 Leveraging 2.4 million COVID-19 vaccine related tweets in 2020, we were able to successfully

312 explore sentiment, emotion, topics, and user demographics to elucidate important trends in

313 public perception about the COVID-19 vaccine. Tweets were overall positive in sentiment and

314 with growing trust. However, fear maintained as a dominant emotion raising concern regarding

315 the willingness to receive the COVID-19 vaccine and subsets of negative sentiment emerged.

316 Comparison to influenza and the influenza vaccine as well as discussion about conspiracy

317 theories were important topics with negative sentiment and showed some demographic

318 differences that could allow for informed intervention. Future work will leverage these natural

319 language processing tools to engage in targeted messaging based on user interests and emotions. 


\section{Declarations}

335 Ethics approval and consent to participate: The University of Texas Southwestern Human

336 Research Protection Program Policies, Procedures, and Guidance did not require institutional

337 review board approval as all data were publicly available.

338 Data Availability, Materials, \& Correspondence: The data that support the findings of this study

339 are available upon request. Please request from the corresponding author.

340 Code Availability: The code that support the findings of this study is available upon

341 request. Please request from the corresponding author.

342 Competing interests: Dr. Lehmann reports stock ownership in Celanese Corporation and Colfax

343 Corporation. There are no other competing interests.

$344 \quad$ Funding: None.

345 Authors' contributions: Study concept and design: SNS, CUL, RJM; Data acquisition: SNS, SK;

346 Analysis: SNS, SK, RJM; Interpretation of data: SNS, SK, CUL, RJM; Manuscript preparation:

347 all authors. All authors read and approved the final manuscript.

$348 \quad$ Acknowledgements: Not applicable 
medRxiv preprint doi: https://doi.org/10.1101/2021.04.19.21255701; this version posted April 22, 2021. The copyright holder for this preprint (which was not certified by peer review) is the author/funder, who has granted medRxiv a license to display the preprint in perpetuity.

It is made available under a CC-BY-NC-ND 4.0 International license .

\section{Figures and Tables}

351 Figure 1. Word cloud of top 300 words related to COVID-19 and vaccine. Larger fonts 352 represent higher frequency in the corpus after preprocessing text.

353

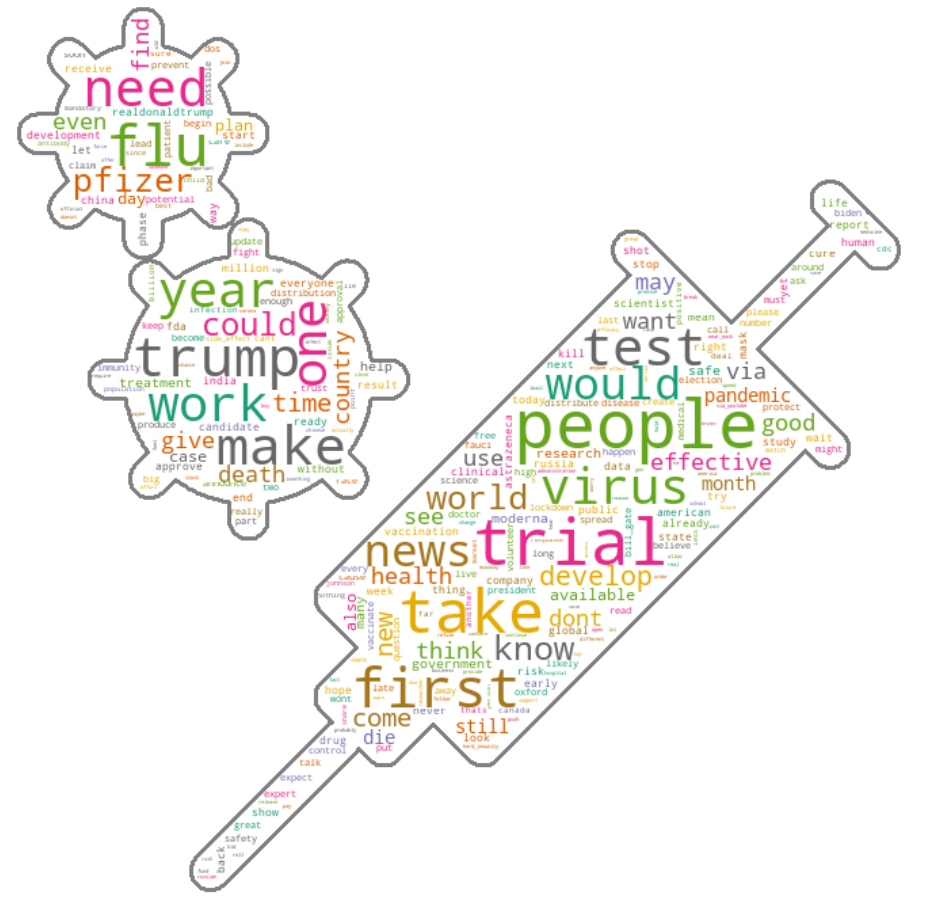


medRxiv preprint doi: https://doi.org/10.1101/2021.04.19.21255701; this version posted April 22, 2021. The copyright holder for this preprint (which was not certified by peer review) is the author/funder, who has granted medRxiv a license to display the preprint in perpetuity.

It is made available under a CC-BY-NC-ND 4.0 International license .

Figure 2a-d. a) Mean sentiment polarity shown by day (as points) and by week (as a dashed

376 line). Each tweet was labeled as primarily negative (-1), neutral (0), or positive (1). b) Mean

377 weekly polarity stratified by individual versus organization. c) Mean weekly polarity stratified

378 by gender for individual accounts. d) Mean weekly polarity stratified by age more or less than 40

379 years than for individual accounts.

a)
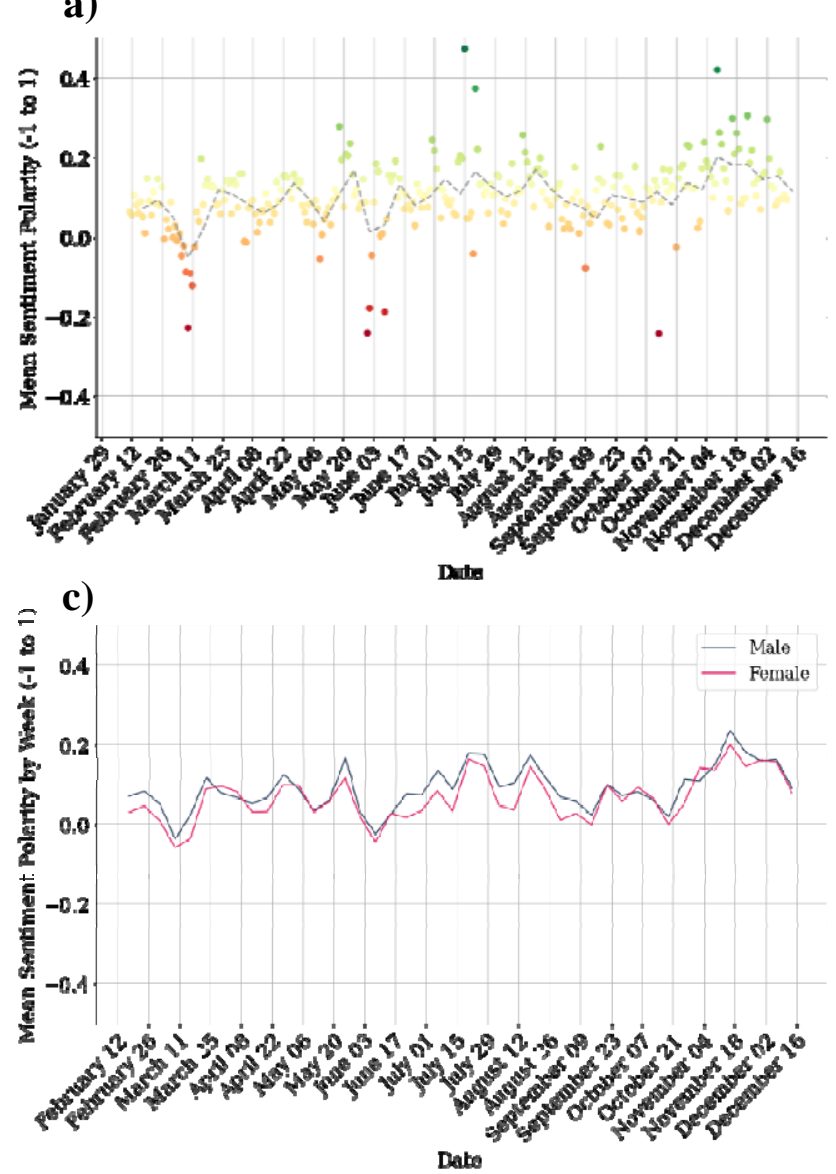

b)
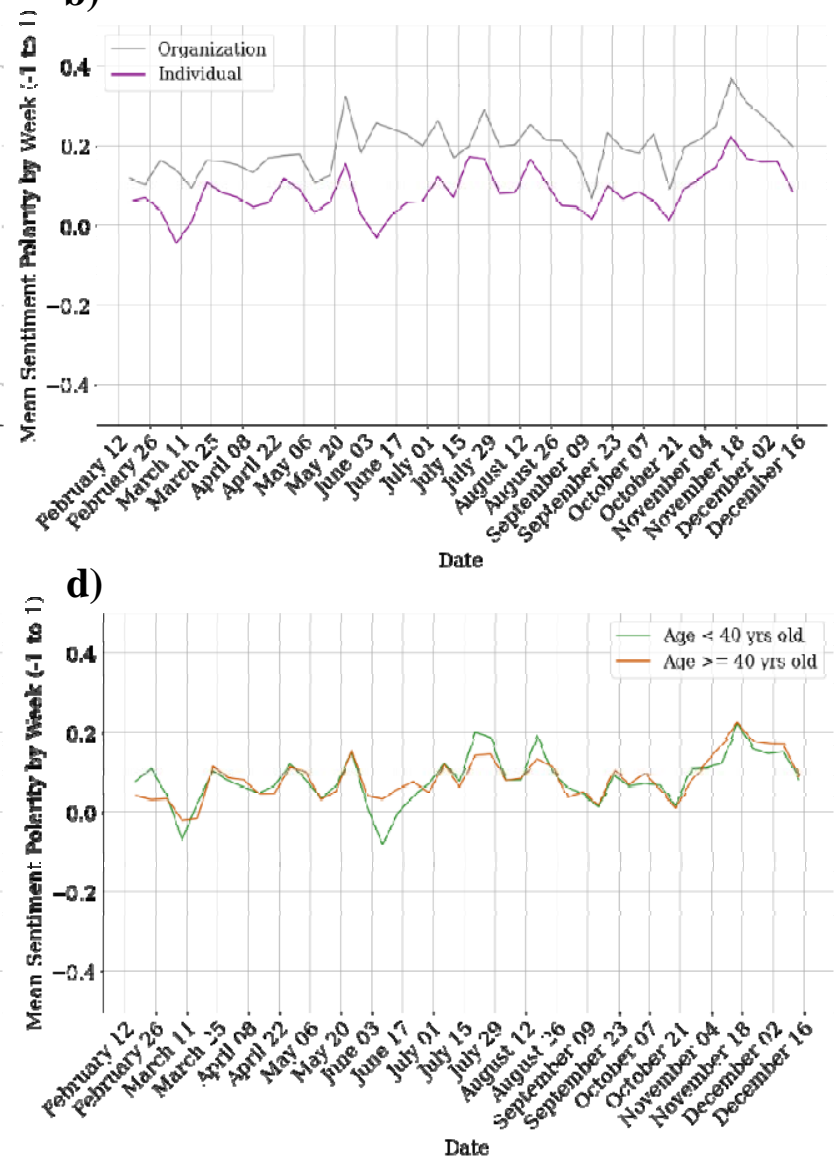
medRxiv preprint doi: https://doi.org/10.1101/2021.04.19.21255701; this version posted April 22, 2021. The copyright holder for this preprint (which was not certified by peer review) is the author/funder, who has granted medRxiv a license to display the preprint in perpetuity.

It is made available under a CC-BY-NC-ND 4.0 International license .

Figure 3a-d. Percent of tweets with primary emotion per month a) overall, b) stratified by individual versus organization, c) stratified by gender for individual accounts, and d) stratified by age more or less than 40 years than for individual accounts. Only tweets with a predominant

a)

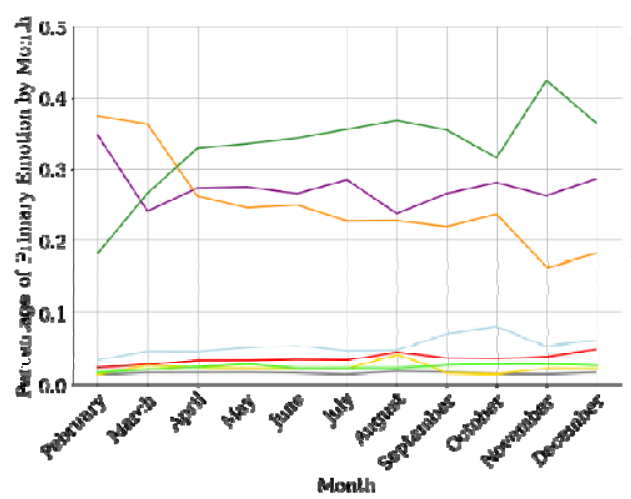

c)

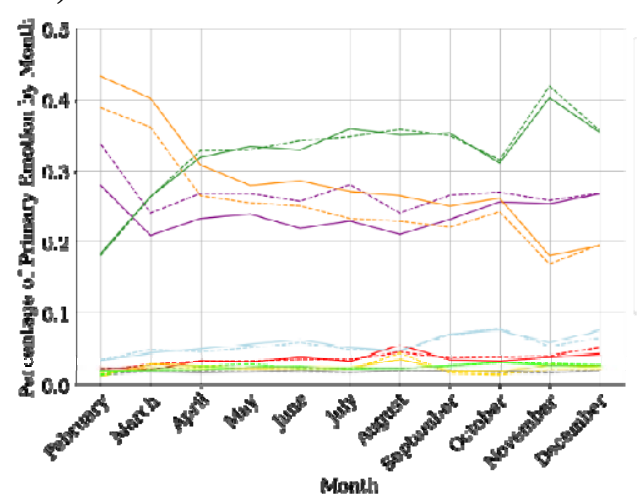

b)
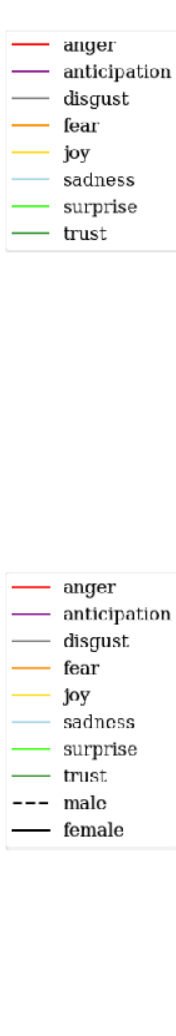

d)
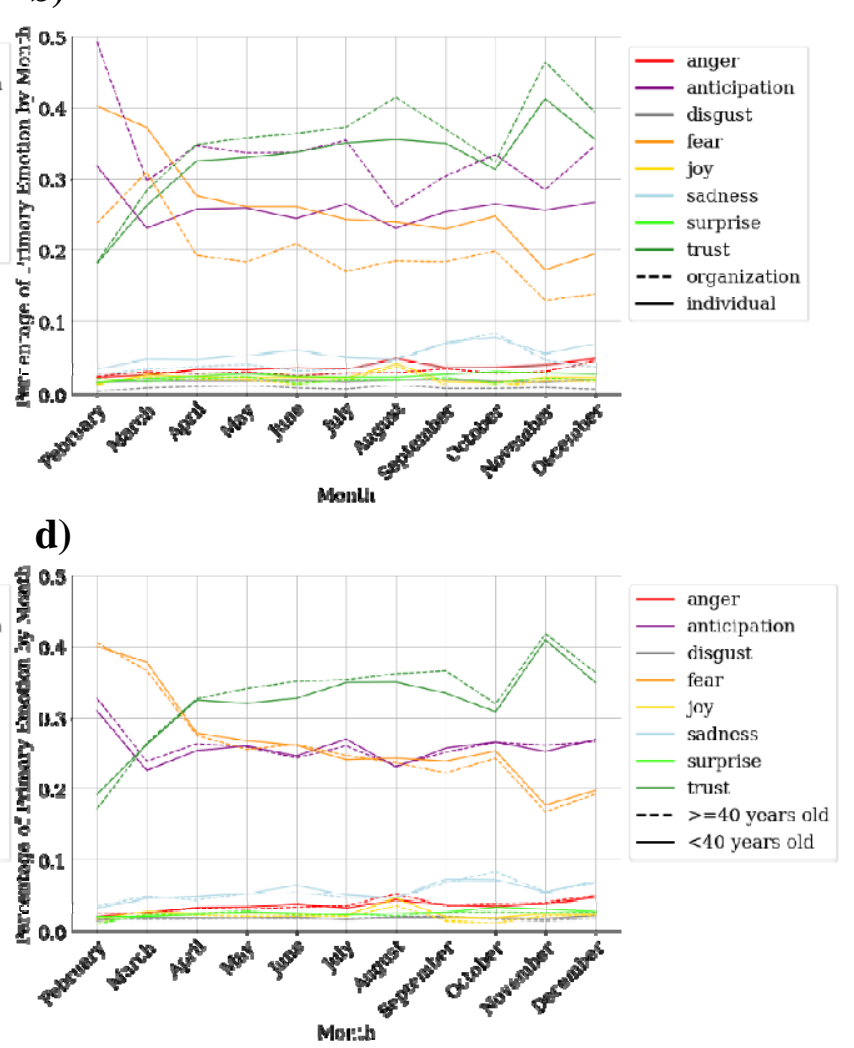

primary emotion $(\mathrm{n}=1,489,027)$ are included. 
medRxiv preprint doi: https://doi.org/10.1101/2021.04.19.21255701; this version posted April 22, 2021. The copyright holder for this preprint (which was not certified by peer review) is the author/funder, who has granted medRxiv a license to display the preprint in perpetuity.

It is made available under a CC-BY-NC-ND 4.0 International license .

395 Figure 4. Heat map showing mean sentiment by month for each topic. Note that a tweet can

396 include multiple topics.

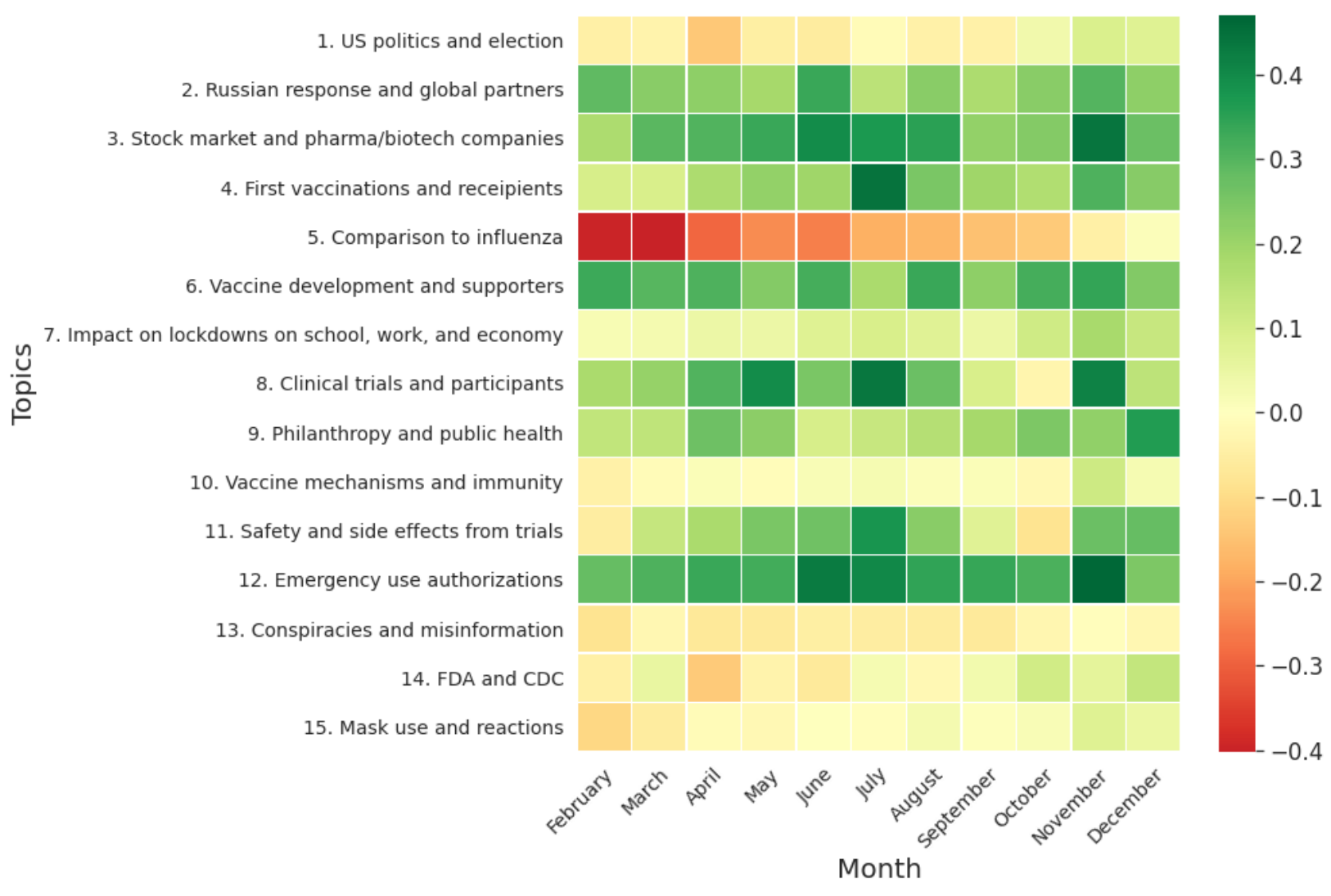


medRxiv preprint doi: https://doi.org/10.1101/2021.04.19.21255701; this version posted April 22, 2021. The copyright holder for this preprint (which was not certified by peer review) is the author/funder, who has granted medRxiv a license to display the preprint in perpetuity.

It is made available under a CC-BY-NC-ND 4.0 International license .

399 Tables

400 Table 1. Tweet and user account characteristics are shown on top and inferred user 401 demographics are shown on bottom.

\begin{tabular}{|c|c|c|c|}
\hline \multicolumn{2}{|c|}{$\begin{array}{c}\text { Tweets } \\
\mathrm{n}=2,287,344\end{array}$} & \multicolumn{2}{|c|}{$\begin{array}{c}\text { User Accounts } \\
\mathrm{N}=948,666\end{array}$} \\
\hline Has link(s) & $1,235,575(54.0)$ & Years account active & $6.9(2.6-10.0)$ \\
\hline Mentions user(s) & $916,585(40.1)$ & Followers & $267(55-1,100)$ \\
\hline Has hashtag(s) & $414,173(18.1)$ & Following & $407(137-1,069)$ \\
\hline Has media & 273,278 (11.9) & Lifetime statuses & $4,605(1,027-16,365)$ \\
\hline Is quoted tweet & $133,404(5.8)$ & Lifetime likes & $3,600(519-15,572)$ \\
\hline Has like & $943,639(41.3)$ & Media shared & $205(36-875)$ \\
\hline Has reply & $548,863(24.0)$ & Public lists, member & $2(0-12)$ \\
\hline Has retweet & $473,204(20.7)$ & Contains description & $800,619(84.4)$ \\
\hline Has quoted tweet & $183,982(8.0)$ & Location listed & $659,720(69.5)$ \\
\hline Twitter source & & Contains profile picture & $902,666(95.2)$ \\
\hline Web App & $686,296(30.0)$ & Contains banner picture & $721,542(76.1)$ \\
\hline iPhone/iPad & $660,382(28.9)$ & Contains link in profile & $303,761(32.0)$ \\
\hline Android & $432,862(18.9)$ & Verified account & $27,443(2.9)$ \\
\hline TweetDeck & $60,845(2.7)$ & & \\
\hline
\end{tabular}

User Demographics

\begin{tabular}{r|r|r|r}
\hline & \multicolumn{2}{|c}{$\mathrm{N}=948,666$} & \\
\hline & & $\mathrm{N}(\%)$ & $\begin{array}{c}\text { Probability } \\
\text { median }(I Q R) \\
\text { Entity }\end{array}$ \\
& Individual & $834,224(87.9)$ & $0.999(0.997-0.999)$ \\
Organization & $114,443(12.1)$ & $0.867(0.727-0.999)$ \\
\hline Sex (of individuals) & Female & $273,400(32.8)$ & $0.992(0.949-0.998)$ \\
\hline Age (of individuals) & Male & $560,824(67.2)$ & $0.996(0.980-0.999)$ \\
\hline
\end{tabular}


medRxiv preprint doi: https://doi.org/10.1101/2021.04.19.21255701; this version posted April 22, 2021. The copyright holder for this preprint (which was not certified by peer review) is the author/funder, who has granted medRxiv a license to display the preprint in perpetuity.

It is made available under a CC-BY-NC-ND 4.0 International license .

\begin{tabular}{r|r}
$\leq 18$ years old & $109,327(13.1)$ \\
19 to 29 years old & $225,360(27.0)$ \\
30 to 39 years old & $169,761(20.4)$ \\
$\geq 40$ years old & $329,776(39.5)$
\end{tabular}

$0.660(0.528-0.821)$

$0.611(50.4-0.754)$

$0.765(0.568-0.936)$

$0.950(0.734-0.996)$

403 Table 2. Topic clusters identified by topic modeling. Words contributing to the model are shown

404 in decreasing order of weighting. The topics are labeled manually based on these words.

\begin{tabular}{|c|c|c|c|c|}
\hline $\begin{array}{l}\text { Possible Topic } \\
\text { Label }\end{array}$ & $\begin{array}{c}\text { Topic } \\
\#\end{array}$ & $\begin{array}{l}\text { Tweets/ } \\
\text { Topic }\end{array}$ & $\begin{array}{c}\text { Words contributing to } \\
\text { topic model } \\
\text { (in } \downarrow \text { order of weighting) }\end{array}$ & Representative Tweet \\
\hline $\begin{array}{l}\text { Mask use and } \\
\text { general } \\
\text { reactions }\end{array}$ & 15 & 811,844 & $\begin{array}{l}\text { people, mask, even, dont, would, } \\
\text { take, know, die, death, need, one, } \\
\text { still, many, kill, risk, never, work, } \\
\text { way, yet, wear_mask }\end{array}$ & $\begin{array}{l}\text { ""Pretty much what it boils down to, at } \\
\text { this point. Ignorance, arrogance, and } \\
\text { stupidity will end up killing LOTS of } \\
\text { people this year, I'm afraid! Be } \\
\text { SMART. WEAR your mask. Wash } \\
\text { your hands. Hold off on large } \\
\text { gatherings until a safe, effective } \\
\text { Covid-19 vaccine arrives. [link]" }\end{array}$ \\
\hline $\begin{array}{l}\text { Conspiracies } \\
\text { and } \\
\text { misinformation }\end{array}$ & 13 & 557,301 & $\begin{array}{l}\text { want, think, fake, make, try, } \\
\text { believe, conspiracy, bill_gate, } \\
\text { money, really, gonna, real, force, } \\
\text { shit, god, anything, anyone, hoax, } \\
\text { black, put }\end{array}$ & $\begin{array}{l}\text { "@ WhiteHouse Also, isnt this a RNA } \\
\text { vaccine? Super experimental albeit } \\
\text { dangerous, could mean with DNA as } \\
\text { well. Human Guinea pigs. Wouldn't be } \\
\text { surprised if the vaccine harms more } \\
\text { then the COVID did." }\end{array}$ \\
\hline $\begin{array}{l}\text { Impact on } \\
\text { lockdowns on } \\
\text { school, work, } \\
\text { and economy }\end{array}$ & 7 & 406,227 & $\begin{array}{l}\text { wait, year, lockdown, open, } \\
\text { month, next, life, time, long, end, } \\
\text { last, come, back, next year, week, } \\
\text { school, ago, day, economy, away }\end{array}$ & $\begin{array}{l}\text { "@[tag] @ }[\mathrm{tag}] @[\mathrm{tag}] @[\mathrm{tag}] \text { And } \\
\text { even with a vaccine they will continue } \\
\text { with the lockdowns, the social distance } \\
\text { and the fear mongering... If not for the } \\
\text { Covid, they will find something..." }\end{array}$ \\
\hline $\begin{array}{c}\text { Vaccine } \\
\text { mechanisms } \\
\text { and immunity }\end{array}$ & 10 & 235,625 & $\begin{array}{l}\text { virus, mrna, immunity, antibody, } \\
\text { prevent, infection, disease, spread, } \\
\text { strain, protein, herd_immunity, } \\
\text { mutate, symptom, } \\
\text { immune_system, sarscov, prevent } \\
\text { infection, mutation, cell, cause, } \\
\text { infect }\end{array}$ & $\begin{array}{l}\text { "If tests show one already had } \\
\text { COVID-19 so one has antibodies and } \\
\text { is now immune, CDC currently counts } \\
\text { that as one infected and positive for } \\
\text { COVID-19. After a vaccine, will } \\
\text { every person vaccinated who therefore } \\
\text { grows antibodies, be considered } \\
\text { positive \& infected? } \\
\text { @ realDonaldTrump" }\end{array}$ \\
\hline $\begin{array}{c}\text { First } \\
\text { vaccinations } \\
\text { and recipients }\end{array}$ & 4 & 232,613 & $\begin{array}{l}\text { first, world, around, world first, } \\
\text { become, first test, receive, country, } \\
\text { first line, first person, world news, } \\
\text { first country, person receive, world } \\
\text { leader, government vote, make }\end{array}$ & $\begin{array}{l}\text { "Thank the lord this is the beginning of } \\
\text { the end: First patient receives Pfizer } \\
\text { Covid-19 vaccine [link]" }\end{array}$ \\
\hline
\end{tabular}




\begin{tabular}{|c|c|c|c|c|}
\hline & & & $\begin{array}{l}\text { sure_pass, yearold_woman, day } \\
\text { government, first dos, first world }\end{array}$ & \\
\hline $\begin{array}{l}\text { Emergency use } \\
\text { authorizations } \\
\text { and approvals }\end{array}$ & 12 & 213,036 & $\begin{array}{l}\text { pfizer, moderna, approval, } \\
\text { effective, pfizer_biontech, } \\
\text { emergency_use, data, biontech, } \\
\text { authorization, receive, regulator, } \\
\text { next_week, approve pfizer, } \\
\text { effective prevent, pfizer ceo, show } \\
\text { effective, moderna effective, } \\
\text { approve, data show, early data }\end{array}$ & $\begin{array}{c}\text { ""Pfizer's Covid vaccine is days away } \\
\text { from approval after data reveals it is } \\
95 \% \text { effective [link]" }\end{array}$ \\
\hline $\begin{array}{l}\text { US politics and } \\
\text { election }\end{array}$ & 1 & 212,597 & $\begin{array}{l}\text { trump, biden, realdonaldtrump, } \\
\text { president, election, } \\
\text { operation_warp, american, credit, } \\
\text { speed, lie, take credit, joebiden, } \\
\text { gop, democrat, potus, win, vote, } \\
\text { joe_biden, admin, america }\end{array}$ & $\begin{array}{l}\text { “@ realDonaldTrump If you want to } \\
\text { take partial credit for the Covid-19 } \\
\text { vaccine fine. You still LOST the } \\
\text { election. In Georgia for example you } \\
\text { are behind there by } 12 \mathrm{k} \text { votes. The } \\
\text { recount wont change the outcome. I } \\
\text { look forward to your predictable reply } \\
\text { and the end of your regime." }\end{array}$ \\
\hline $\begin{array}{l}\text { Stock market } \\
\text { and } \\
\text { pharma/biotech } \\
\text { companies }\end{array}$ & 3 & 205,557 & $\begin{array}{l}\text { market, stock, news, company, } \\
\text { good news, biotech, drug } \\
\text { company, pharma, price, billion, } \\
\text { drug, surge, late, update, rise, } \\
\text { break news, positive news, } \\
\text { investor, pharma company, } \\
\text { announce }\end{array}$ & $\begin{array}{l}\text { "Markets are supported by both the } \\
\text { cumulative upside surprises to the } \\
\text { economy since the end of the recession } \\
\text { and the apparently faster-than-expected } \\
\text { progress toward a COVID-19 vaccine. } \\
\text { [link]" }\end{array}$ \\
\hline $\begin{array}{l}\text { Clinical trials } \\
\text { and } \\
\text { participants }\end{array}$ & 8 & 205,468 & $\begin{array}{l}\text { trial, clinical, human trial, phase, } \\
\text { human, volunteer, participant, } \\
\text { oxford, begin, phase clinical, } \\
\text { show, trial participant, result, } \\
\text { volunteer trial, ahead_large trial, } \\
\text { ahead_large, show_promise, } \\
\text { immune_response, test, number }\end{array}$ & $\begin{array}{c}\text { "Coronavirus Vaccine Update } \mid \\
\text { Oxford's COVID-19 vaccine trial in } \\
\text { Brazil begins: Scientists say } \\
\text { coronavirus jab may not work for older } \\
\text { adults [link]" }\end{array}$ \\
\hline $\begin{array}{c}\text { Vaccine } \\
\text { development } \\
\text { and supporters }\end{array}$ & 6 & 204,083 & $\begin{array}{l}\text { research, development, global, } \\
\text { effort, develop, fund, researcher, } \\
\text { global effort, join, effort develop, } \\
\text { access, help, target, hacker, } \\
\text { treatment, support, dolly_parton, } \\
\text { research development, accelerate, } \\
\text { collaboration }\end{array}$ & $\begin{array}{l}\text { "As the world continues to feel the } \\
\text { impact of COVID-19, the } \\
\text { biopharmaceutical industry is working } \\
\text { around the clock to identify and } \\
\text { develop safe and effective vaccines to } \\
\text { prevent infection, while also } \\
\text { researching and developing new } \\
\text { therapies to treat those infected with } \\
\text { the virus." }\end{array}$ \\
\hline $\begin{array}{c}\text { Russian } \\
\text { response and } \\
\text { global partners }\end{array}$ & 2 & 187,369 & $\begin{array}{l}\text { russia, india, via, sputnik, russian, } \\
\text { china, putin, serum_institute, } \\
\text { indian, covaxin, chinese, } \\
\text { bharat_biotech, icmr, } \\
\text { hacker_target, time india, via } \\
\text { nbcnews, russia sputnik, } \\
\text { indias_serum, narendramodi, } \\
\text { possible }\end{array}$ & $\begin{array}{l}\text { "A Sputnik moment, president \#Putin } \\
\text { has announced that \#Russia is the first } \\
\text { country in the world to register a } \\
\text { \#Covid_19 vaccine. } 10 \text { s of countries } \\
\text { already requested it [link]" }\end{array}$ \\
\hline FDA and CDC & 14 & 179,396 & $\begin{array}{l}\text { trump, fda, failure, administration, } \\
\text { trump administration, fda } \\
\text { approval, food_drug, food_drug } \\
\text { administration, fda approve, cdc, }\end{array}$ & $\begin{array}{l}\text { “'@CDCgov if you try and push } \\
\text { through an unproven vaccine because } \\
\text { of Trump's desperation to recover } \\
\text { from his abysmal handling of Covid- }\end{array}$ \\
\hline
\end{tabular}


medRxiv preprint doi: https://doi.org/10.1101/2021.04.19.21255701; this version posted April 22, 2021. The copyright holder for this preprint (which was not certified by peer review) is the author/funder, who has granted medRxiv a license to display the preprint in perpetuity.

It is made available under a CC-BY-NC-ND 4.0 International license .

\begin{tabular}{|c|c|c|c|c|}
\hline & & & $\begin{array}{l}\text { trump admin, white_house, trump } \\
\text { claim, president_donald trump, } \\
\text { president_donald, cuomo, trump } \\
\text { supporter, want, take, } \\
\text { exist_sustainable }\end{array}$ & $\begin{array}{l}\text { 19...good luck. No one I know myself } \\
\text { included will be getting vaccinated." }\end{array}$ \\
\hline $\begin{array}{l}\text { Philanthropy } \\
\text { and public } \\
\text { health }\end{array}$ & 9 & 156,183 & $\begin{array}{c}\text { health, public, mandatory, public } \\
\text { health, health official, health care, } \\
\text { public trust, official, gavi_sdg, } \\
\text { cdc_gatesfoundation, } \\
\text { read_billgates } \\
\text { cdc_gatesfoundation, gavi_sdg } \\
\text { vaccination, make mandatory, } \\
\text { read_billgates, health expert, } \\
\text { care_worker, health minister, } \\
\text { health care_worker, clinton, } \\
\text { obama_bush }\end{array}$ & $\begin{array}{l}\text { "@ }[\operatorname{tag}] \text { This presents a problem and } \\
\text { crashes into the argument, should } \\
\text { covid vaccines be mandated. I initially } \\
\text { thought that it will need more then } \\
\text { encouragement and common sense } \\
\text { from the public but these vaccine } \\
\text { deniers are going to deprive people of } \\
\text { protection through fear. Arrest them." }\end{array}$ \\
\hline $\begin{array}{l}\text { Comparison to } \\
\text { influenza }\end{array}$ & 5 & 151,177 & $\begin{array}{l}\text { flu, shot, influenza, flu shot, every } \\
\text { year, season, seasonal, die flu, } \\
\text { every, flu death, year flu, kill, jab, } \\
\text { take flu, first shot, virus, people, } \\
\text { side_effect shot, compare, via }\end{array}$ & $\begin{array}{l}\text { “'Ok so I'm usually not super crunchy } \\
\text { about everything but I've been } \\
\text { hospitalized } 2 \mathrm{x} \text { after getting the flu } \\
\text { shot bc of how badly I got the flu } \\
\text { within months so I was told not to get } \\
\text { the shot by my drs. what does that } \\
\text { mean for COVID's vaccine? Like what } \\
\text { if I react the same?" }\end{array}$ \\
\hline $\begin{array}{l}\text { Safety and side } \\
\text { effects from } \\
\text { trials }\end{array}$ & 11 & 137,445 & $\begin{array}{l}\text { astrazeneca, safety, effect, johnson } \\
\text { johnson, pause, study, } \\
\text { unexplained_illness, astrazeneca } \\
\text { trial, johnson_pause, long_term } \\
\text { effect, oxford_university, pause } \\
\text { trial, safety efficacy, efficacy, } \\
\text { safety concern, resume, put hold, } \\
\text { astrazeneca study, illness, side }\end{array}$ & $\begin{array}{l}\text { 'AstraZeneca COVID-19 vaccine study } \\
\text { put on hold due to suspected adverse } \\
\text { reaction in UK participant [link]" }\end{array}$ \\
\hline
\end{tabular}


medRxiv preprint doi: https://doi.org/10.1101/2021.04.19.21255701; this version posted April 22, 2021. The copyright holder for this preprint (which was not certified by peer review) is the author/funder, who has granted medRxiv a license to display the preprint in perpetuity. It is made available under a CC-BY-NC-ND 4.0 International license .

\section{References}

408 1. Sridhar, D. \& Gurdasani, D. Herd immunity by infection is not an option. Science 371, 230$409231(2021)$.

410 2. Forni, G., Mantovani, A., \& COVID-19 Commission of Accademia Nazionale dei Lincei, 411 Rome. COVID-19 vaccines: where we stand and challenges ahead. Cell Death Differ 28, $412 \quad 626-639(2021)$.

413 3. Caserotti, M. et al. Associations of COVID-19 risk perception with vaccine hesitancy over 414 time for Italian residents. Soc Sci Med 272, 113688 (2021).

415 4. Wong, M. C. S. et al. Acceptance of the COVID-19 vaccine based on the health belief 416 model: A population-based survey in Hong Kong. Vaccine 39, 1148-1156 (2021).

417 5. Feleszko, W., Lewulis, P., Czarnecki, A. \& Waszkiewicz, P. Flattening the Curve of 418 COVID-19 Vaccine Rejection-An International Overview. Vaccines (Basel) 9, (2021).

419 6. Ten threats to global health in 2019. https://www.who.int/news-room/spotlight/ten-threats420 to-global-health-in-2019.

421 7. Alley, S. J. et al. As the Pandemic Progresses, How Does Willingness to Vaccinate against 422 COVID-19 Evolve? Int J Environ Res Public Health 18, (2021).

423 8. Reiter, P. L., Pennell, M. L. \& Katz, M. L. Acceptability of a COVID-19 vaccine among 424 adults in the United States: How many people would get vaccinated? Vaccine 38, 6500-6507 $425 \quad$ (2020).

426 9. Malik, A. A., McFadden, S. M., Elharake, J. \& Omer, S. B. Determinants of COVID-19 $427 \quad$ vaccine acceptance in the US. EClinicalMedicine 26, 100495 (2020). 
medRxiv preprint doi: https://doi.org/10.1101/2021.04.19.21255701; this version posted April 22, 2021. The copyright holder for this preprint (which was not certified by peer review) is the author/funder, who has granted medRxiv a license to display the preprint in perpetuity. It is made available under a CC-BY-NC-ND 4.0 International license .

10. Shaw, J. et al. Assessment of U.S. health care personnel (HCP) attitudes towards COVID-19 vaccination in a large university health care system. Clin Infect Dis (2021) doi:10.1093/cid/ciab054.

11. Verger, P. et al. Attitudes of healthcare workers towards COVID-19 vaccination: a survey in France and French-speaking parts of Belgium and Canada, 2020. Euro Surveill 26, (2021).

12. Saleh, S. N., Lehmann, C. U. \& Medford, R. J. Early Crowdfunding Response to the COVID-19 Pandemic: Cross-sectional Study. J Med Internet Res 23, e25429 (2021).

13. Q3 2020 Letter to Shareholders. https://s22.q4cdn.com/826641620/files/doc_financials/2020/q3/Q3-2020-Shareholder-

$437 \quad$ Letter.pdf.

14. McGraw, T. Spending 2020 Together on Twitter. https://blog.twitter.com/en_us/topics/insights/2020/spending-2020-together-on-twitter.html.

440 15. Stieglitz, S. \& Dang-Xuan, L. Emotions and Information Diffusion in Social Media-

441 Sentiment of Microblogs and Sharing Behavior. Journal of Management Information Systems 29, 217-248 (2013).

443 16. Depoux, A. et al. The pandemic of social media panic travels faster than the COVID-19 $444 \quad$ outbreak. Journal of Travel Medicine 27, taaa031 (2020).

445 17. Sinnenberg, L. et al. Twitter as a Tool for Health Research: A Systematic Review. Am J $446 \quad$ Public Health 107, e1-e8 (2017).

447 18. Chang, C.-H., Monselise, M. \& Yang, C. C. What Are People Concerned About During the 448 Pandemic? Detecting Evolving Topics about COVID-19 from Twitter. J Healthc Inform Res 1-28 (2021) doi:10.1007/s41666-020-00083-3. 
medRxiv preprint doi: https://doi.org/10.1101/2021.04.19.21255701; this version posted April 22, 2021. The copyright holder for this preprint (which was not certified by peer review) is the author/funder, who has granted medRxiv a license to display the preprint in perpetuity. It is made available under a CC-BY-NC-ND 4.0 International license .

19. Chandrasekaran, R., Mehta, V., Valkunde, T. \& Moustakas, E. Topics, Trends, and Sentiments of Tweets About the COVID-19 Pandemic: Temporal Infoveillance Study. Journal of Medical Internet Research 22, e22624 (2020).

20. Xue, J. et al. Twitter Discussions and Emotions About the COVID-19 Pandemic: Machine Learning Approach. Journal of Medical Internet Research 22, e20550 (2020).

21. Gallotti, R., Valle, F., Castaldo, N., Sacco, P. \& De Domenico, M. Assessing the risks of 'infodemics' in response to COVID-19 epidemics. Nature Human Behaviour 4, 1285-1293 (2020).

22. Medford, R. J., Saleh, S. N., Sumarsono, A., Perl, T. M. \& Lehmann, C. U. An 'Infodemic': Leveraging High-Volume Twitter Data to Understand Early Public Sentiment for the

23. Saleh, S. N., Lehmann, C. U., McDonald, S. A., Basit, M. A. \& Medford, R. J. Understanding public perception of coronavirus disease 2019 (COVID-19) social distancing

24. Systematic scoping review on social media monitoring methods and interventions relating to vaccine hesitancy. https://www.ecdc.europa.eu/en/publications-data/systematic-scoping-

25. Salathé, M. \& Khandelwal, S. Assessing Vaccination Sentiments with Online Social Media: e1002199 (2011).

26. Dunn, A. G. et al. Mapping information exposure on social media to explain differences in HPV vaccine coverage in the United States. Vaccine 35, 3033-3040 (2017). 
medRxiv preprint doi: https://doi.org/10.1101/2021.04.19.21255701; this version posted April 22, 2021. The copyright holder for this preprint (which was not certified by peer review) is the author/funder, who has granted medRxiv a license to display the preprint in perpetuity.

It is made available under a CC-BY-NC-ND 4.0 International license .

472

473

474

475

476

477

478

479

480

481

482

483

484

485

486

487

488

489

490

491

492

493

494

27. Wilson, S. L. \& Wiysonge, C. Social media and vaccine hesitancy. BMJ Global Health 5, e004206 (2020).

28. FDA Takes Key Action in Fight Against COVID-19 By Issuing Emergency Use Authorization for First COVID-19 Vaccine. https://www.fda.gov/news-events/press-announcements/fdatakes-key-action-fight-against-covid-19-issuing-emergency-use-authorization-first-covid-19.

29. Snscrape. (Github).

30. Frijda, N. H. The emotions. (Cambridge University Press $\square$; Editions de la Maison des sciences de l'homme, 1986).

31. Hutto, C. \& Gilbert, E. ). VADER: A Parsimonious Rule-based Model for Sentiment Analysis of Social Media Text. in (2014).

32. Loria, S. Textblob: simplified text processing. (Textblob).

33. Mohammad, S. M. \& Turney, P. D. Emotions evoked by common words and phrases: using mechanical turk to create an emotion lexicon. in Proceedings of the NAACL HLT 2010 Workshop on Computational Approaches to Analysis and Generation of Emotion in Text 2634 (Association for Computational Linguistics, 2010).

34. Gallagher, R. J., Reing, K., Kale, D. \& Steeg, G. V. Anchored Correlation Explanation: Topic Modeling with Minimal Domain Knowledge. arXiv:1611.10277 [cs, math, stat] (2018).

35. Steeg, G. V. \& Galstyan, A. Discovering Structure in High-Dimensional Data Through Correlation Explanation. arXiv:1406.1222 [cs, stat] (2014).

36. Wang, Z. et al. Demographic Inference and Representative Population Estimates from Multilingual Social Media Data. in The World Wide Web Conference 2056-2067 (ACM, 2019). doi:10.1145/3308558.3313684. 
medRxiv preprint doi: https://doi.org/10.1101/2021.04.19.21255701; this version posted April 22, 2021. The copyright holder for this preprint (which was not certified by peer review) is the author/funder, who has granted medRxiv a license to display the preprint in perpetuity.

It is made available under a CC-BY-NC-ND 4.0 International license .

37. Yang, Y.-C., Al-Garadi, M. A., Love, J. S., Perrone, J. \& Sarker, A. Automatic Gender Detection in Twitter Profiles for Health-related Cohort Studies. http://medrxiv.org/lookup/doi/10.1101/2021.01.06.21249350 (2021) doi:10.1101/2021.01.06.21249350.

38. Pfizer and Biontech announce Vaccine Candidate against Covid-19 Achieved Success in First Interim Analysis From Phase 3 Study. https://www.pfizer.com/news/pressrelease/press-release-detail/pfizer-and-biontech-announce-vaccine-candidate-against.

39. AJMC Staff. A Timeline of COVID-19 Developments in 2020. AJMC (2021).

40. Jackson, L. A. et al. An mRNA Vaccine against SARS-CoV-2 - Preliminary Report. $N$ Engl J Med 383, 1920-1931 (2020).

41. Subbaraman, N. This COVID-vaccine designer is tackling vaccine hesitancy - in churches and on Twitter. Nature 590, 377 (2021).

42. Loomba, S., de Figueiredo, A., Piatek, S. J., de Graaf, K. \& Larson, H. J. Measuring the impact of COVID-19 vaccine misinformation on vaccination intent in the UK and USA. Nat

510 43. Shearer, E. \& Mitchell, A. News Use Across Social Media Platforms in 2020. https://www.journalism.org/2021/01/12/news-use-across-social-media-platforms-in-2020/ (2021).

513 44. Damiano, A. D. \& Allen Catellier, J. R. A Content Analysis of Coronavirus Tweets in the $514 \quad$ United States Just Prior to the Pandemic Declaration. Cyberpsychol Behav Soc Netw 23, $515 \quad 889-893(2020)$. 
medRxiv preprint doi: https://doi.org/10.1101/2021.04.19.21255701; this version posted April 22, 2021. The copyright holder for this preprint (which was not certified by peer review) is the author/funder, who has granted medRxiv a license to display the preprint in perpetuity. It is made available under a CC-BY-NC-ND 4.0 International license.

516 45. Jang, H., Rempel, E., Roth, D., Carenini, G. \& Janjua, N. Z. Tracking COVID-19 Discourse

517 on Twitter in North America: Infodemiology Study Using Topic Modeling and Aspect-

$518 \quad$ Based Sentiment Analysis. J Med Internet Res 23, e25431 (2021).

519 46. Kemp, S. Digital 2020 Global Digital Overview.

520 https://p.widencdn.net/1zybur/Digital2020Global_Report_en (2020).

521 47. Fontanet, A. \& Cauchemez, S. COVID-19 herd immunity: where are we? Nat Rev Immunol

$522 \quad 20,583-584(2020)$.

523 48. McNeil Jr., D. G. https://www.nytimes.com/2020/12/24/health/herd-immunity-covid-

$524 \quad$ coronavirus.html. The New York Times (2021).

525 49. Randolph, H. E. \& Barreiro, L. B. Herd Immunity: Understanding COVID-19. Immunity 52 , $526 \quad 737-741(2020)$. 